Article

\title{
Perceived Impact of Border Closure due to Covid-19 of Intending Nigerian Migrants
}

\author{
Lawan Cheri \\ Department of Public Administration, Yobe State University, 620242 Damaturu, Nigeria; E-Mail: lawan.cheri@ysu.edu.ng
}

Submitted: 18 September 2020 | Accepted: 19 November 2020 | Published: 25 March 2021

\begin{abstract}
With few exceptions, the European Council closed Europe for non-citizen travellers on 17 March 2020 because of the Covid-19 pandemic. Many African countries, including Nigeria, have placed travel restrictions on or completely shut their borders to both travellers who want to enter the country and citizens who want to leave. These decisions affect many intending migrants seeking a way to reach Europe. Health and socioeconomic uncertainties related to lockdowns, border closure, and in some cases travel restrictions directly affect the dynamics of decision-making by migrants. This article employs in-depth interviews and focus group discussions to explore the perception of Nigerians who intend to migrate considering the influence of Covid-19. The study focuses on Nigerian migrants but touches on Nigerians in transit who are trapped in Niger en route to Europe through Libya and Morocco. While border closure by most of the sending and receiving countries led to a decrease in the intention of migrants to travel, Covid-19 as a pandemic does not significantly influence migrants' decisions primarily because of its global presence, merely leading to delays. In conclusion, after border reopening, intercontinental migration is expected to increase in both volume and intensity.
\end{abstract}

\section{Keywords}

border closure; Covid-19; lockdown; migration; mobility; Nigerian migrants; travel restrictions

Issue

This article is part of the issue "Decision-Making under Uncertainty: African Migrants in the Spotlight" edited by Didier Ruedin (University of the Witwatersrand, South Africa / University of Neuchâtel, Switzerland).

(C) 2021 by the author; licensee Cogitatio (Lisbon, Portugal). This article is licensed under a Creative Commons Attribution 4.0 International License (CC BY).

\section{Introduction}

Covid-19 has become a health pandemic, but its impacts transcends health sectors and affect socioeconomic, political, diplomatic and, not least, migration trends. Lockdowns, travel restrictions, curfews, industrial closure and social distancing are making economic activities very difficult in most countries and completely impossible in some (World Bank, 2020d). This affects transportation especially in regions where entry into and exit from a country is banned. In this article we look at the case of Nigeria (John, 2020).

Studying the trend of migration in times of Covid-19 and its concomitant impacts becomes pertinent to unveil the effects of the pandemic in constraining migrants from travelling out, the impact of movement restrictions on labour shortages in receiving countries, as well as how anti-migration groups can exploit the fear created by the pandemic and masquerade it as a potential solution to a global health problem by pushing for strict legislations against migration (Natter, Czaika, \& Haas, 2020). Exploring the potentials of these dynamics can provide insights that could aid policy development and preparation for a post-Covid-19 migration world-where fear, stigmatisation and global health politics are expected to govern migration, or at least influence it. It therefore points to the imperative of studying the uncertainties of migration amidst non-conflict restrictions such as temporary border closure.

Research linking migration to Covid-19 focus heavily on predicting the risk exposures of migrants and hosts (Ahsan, Iqbal, Khan, \& Mobarak, 2020) and how the pandemic may change perception of people from hostility towards migrants to the realisation of human oneness and acceptance (Xhardez, 2020), while some topics dwell on its impact on laws and policies. Some studies 
take a broader and generalised study of the impact of Covid-19 on migration including its effects on labour migration and the potential loss of migrant workforce in industries, probability of increase in inequality including racism and social exclusion, possible support for politicians with anti-immigrant far right ideology which could shut the door against millions of vulnerable migrants and resultant increase in irregular migration (Yayboke, 2020). While (Ramji-Nogales \& Lang, 2020) and Yayboke (2020) heavily rely on anecdotes and policy briefs, this article explores the perception of intending migrants and documented their experiences, feeling, fears, hopes and thoughts. The survey was limited to Nigerian migrants that intend to migrate to Europe, which makes it particularly confined to African experiences of both regular and irregular migration patterns as they are affected by the pandemic. This article documents how intending migrants perceive the effects of Covid-19 on their decision to migrate, the conditions they live in transit countries and their expectations in a post-Covid-19 world.

\section{Objectives of the Study}

Our main objective was to examine the perception of intending Nigerian migrants on border closing due to the Covid-19 pandemic and its impact on migration. Our main goals were as follows:

1. Examine the effect of Covid-19 on Nigerians' decision to migrate to Europe.

2. Assess the socioeconomic conditions of migrants on transit.

3. Examine post-Covid-19 expectations of intending Nigerian migrants.

\section{Theory}

"International migration...is continuously on the rise in an increasingly globalized context with substantial implications for population health policy and research" (Hossin, 2020). This statement captures vividly the intricate relationship between migration, policy change and the real or perceived health challenges that migrants present in the health dynamics of their receiving populations. Lockdowns, social distancing, intra-city movement restrictions and international travel bans brought untold difficulties to economic endeavours, leading to layoffs, diminishing economic activities, standstills and the outright closure of companies and other group associations (World Bank, 2020a). This foretells significant change, not only regarding migrant labour dynamics but also on matters of social acceptance or exclusion, stigmatization and racism.

Thus, while Covid-19 is a health issue, it has implications on all aspects of human life, including the economy, politics and policy making, migration and immobility. The pandemic presents far-right politicians in receiving countries with ample opportunity to push anti-immigrant policies that could restrict mobility (Gagnon, 2020). Justifiably, the weak testing capacity of countries in the Global South could render people migrating to Europe from Africa and Asia susceptible to discrimination, exclusion, denial or outright violence (Ahsan et al., 2020).

Remittances are major sources of foreign exchange in most countries of Sub-Saharan Africa. With the sudden stoppage of economic activities in Europe, increase in the rate of poverty in sending nations can be reasonably expected. This can constitute a push factor and fuel interest to migrate especially to countries that are anticipated to be able to bounce back from the economic effects of the pandemic. Within Sub-Saharan Africa, Nigeria remains the highest recipient of remittances (with $\$ 23.8$ billion in 2019) far ahead of Ghana and Kenya (with $\$ 3.4$ billion and $\$ 2.8$ billion respectively; World Bank, 2020a). With a population of 200 million people, an increase in poverty and deprivation in Nigeria is likely to bring about alarming consequences, such as the fuelling of existing conflicts like Boko Haram insurgency in the Northeast, IPOB secessionist movements in the Niger-Delta and the Farmers-Herders conflict in North Central regions, all of which can push more people towards emigration.

This article interrogates the potency of Covid-19 in altering migration dynamics among intending Nigerian migrants who seek to travel to Europe but were inadvertently constrained by the pandemic and its concomitant travel policy changes. Do migrants respond to these restrictions by shelving their intention to move to Europe, or do they only bring their intentions to a temporary halt, pending lifting of travel bans?

\subsection{Methods and Data}

Data was collected from intending Nigerian migrants who are constrained by the pandemic and forced to stay and those who commenced irregular migration from Nigeria to Europe but got stranded in Niger republic en route to Europe via Libya/Morocco. The data were collected in two major streams, first from three officials of the Nigerian Immigration Service, then from interviews to 18 intending migrants. There was also one session of a focus group discussion held with seven migrants trapped in the Republic of the Niger. Purposive and snowball sampling were employed to identify a total of 28 respondents10 in Nigeria and 18 in Niger. Respondents were identified through a snowball exercise where one respondent led us to the next. The group discussion in Niger was the result of time constraints: The seven migrants were not covered individually because they were working in a building site and we could only interview them during their one-hour break. Out of the 28 respondents, 21 are male and seven are female. They were engaged in discussions and the data collected were analysed using thematic narrative analysis of stakeholder submissions.

Respondents were given full freedom to choose whether to be interviewed or not and the right to 
disengage at any point as well as the freedom not to answer any question they might not be comfortable with. Conditional consent was obtained from those that participated in the survey based on the principle of 'do no harm' and a pledge of utmost confidentiality. Those who did not agree were not interviewed. Transcribed interviews were the main focus of the analysis with emphasis on contents that offered insights into the main research questions. Interview contents were then compared against the research questions to identify patterns, which were latter grouped into sub-themes and presented in narratives. The identified themes were then analysed. Some statements that summarised common grounds are picked and presented in this article. The main theme of the interviews was to examine the extent to which Covid-19 and its concomitant travel restrictions affect the willingness of intending Nigerian migrants to reach Europe. We assess the hindrances that inhibit Nigerian migrants' movements, their fears, expectations and plans towards achieving their travel objectives.

The responses of all Nigerian intending migrants who aim to reach Europe are often presented as one: Although the data were collected from them individually, the analysis focuses on commonalities and does not systematically discuss individual cases. Doing so respects the wish of real anonymity among the participants, because almost all of those who travel through Niger to Europe are irregular migrants.

\section{Findings: How Covid-19 Border Closure Affects Migration Decisions among Nigerian Migrants}

Interviews with migrants who are still in Nigeria show that the lockdown in the major cities of Abuja and Lagos halted the formal processes of regular migration, making it impossible for migrants to travel legally. However, they remain firm on their decision to settle in Europe, thereby considering the hitches as only temporary. A 33-year-old migrant opined:

Consular offices were closed indefinitely, which means even if we want to go ahead with preparations and wait for the borders to be opened, we cannot do that. This simply means everything is halted, but we know it is temporary.

This also indicates that though many migrants travel through irregular ways, a number of them pursue their European dreams through the formal, regular patterns. However, consular offices of many European countries resumed after relative successes against the pandemic (Artis, Carlei, \& Bouteller, 2020; Chike, 2020).

Regardless of Covid-19 and its associated travel restrictions, most West African countries exempt transporters of food and medication from travel restrictions, prompting some irregular migrants to attempt and move on lorries to the next destination. There are stories of success among migrants trapped in Agadez and Dirkou in Niger. Around two thirds of the respondents did not have intention of cancelling their migration plans; they only consider temporarily postponing them. About one third of respondents wanted to cancel their travel plans for different reasons largely due to the economic hardship wrought by Covid-19 and general economic turbulence in transit countries. This is supported by the recent research that reveals that migrants are heavily affected by lockdowns and movement restrictions (Migration Data Portal, 2020). However, after lifting the lockdown and travel restrictions, the situation may change due to the possible reduction of economic pressures and resurfacing of opportunities that will support the journey. A respondent remarked: "We are praying and waiting to see what God will do, but if the situation does not improve, I will go back to my farm."

Maintaining their intention to migrate means waiting for the lifting of travel restrictions or moving through illegal, difficult and dangerous routes. In other words, due to the historical and cultural similarities of West Africans and the porous borders between countries, migrants take irregular routes and evade official checks at the borders to arrive at their next transit countries. Nigeria shares a border of 1,497 kilometres with Niger, 1,690 kilometres with Cameroon and 87 kilometres with Chad. Along this stretch there are more than 1500 illegal crossing routes that are increasingly difficult to monitor, especially because of the security challenges posed by armed groups (Bearzotti, Geranio, Keresztes, \& Müllerová, 2015). This answers why the European Union and other international actors like the International Organisation for Migration (IOM), the Spanish Guardia Civil, the German GIZ and the European Development Fund invested heavily in the provision of training and equipment to intensify and strengthen border controls in African countries in order to guard against migration and terrorism (Frowd, 2014), as well as making arrangements for Sub-Saharan countries to readmit returning migrants and clamp down on irregular migration in exchange for development aid-all as means of externalising border control (Haas, 2008). A secondary decision that migrants mostly take is paying for services of travel agents that smuggle travellers to Europe and end up dehumanising migrants on the way and at their destinations. A stranded 34-year old male migrant in Agadez narrated how he was separated from his wife and young child:

We paid $\mathrm{A} 470,000$ [corresponding to about 15 months' minimum wage in Nigeria] to an agent to take us to Europe. When we reached Morocco we were separated into four groups to avoid being detected if we move as a large group. The group of my wife and daughter entered Spain, but our group was arrested by Moroccan authorities and detained for months before we were deported back home. I worked hard to save money and reunite with my family and having reached here, the borders are closed because of 
Corona, but we hope it will be opened soon, and we will reach Morocco.

Caused by socioeconomic problems in Africa, the scourge of human trafficking and smuggling along the Mediterranean routes has been a serious problem in West Africa for decades (Fleshman, 2009; Sawadogo, 2012; Triandafyllidou \& McAuliffe, 2018), which resulted in concerted efforts by African and European nations to tackle it (United Nations Office on Drugs and Crime [UNODC], 2018). Regardless this collaboration, the significance of migration led scholars to conclude that "despite lip service being paid to combating illegal migration for political and diplomatic reasons, neither European nor African states have much genuine interest in stopping migration" (Haas, 2008). In addition, while the externalization of borders by European authorities facilitates the goal of the Economic Community of West African States (ECOWAS), which is to optimise regular migration to Europe, it also affects free intra-regional movement in the region, which is also one of the objectives of ECOWAS (2008). Argued in another way, the prevalence of human trafficking and smuggling across the Sahara to Europe only garnered momentum when European countries sought to externalize border controls and encouraged African countries to illegalize movements across the Sahara regardless of the ECOWAS free movement protocols (Brachet, 2018), resulting not only in failure of the European fight against 'invasion,' but also in an increased, albeit clandestine, movement across the Mediterranean. This is especially so after the adoption by Niger of a law against smuggling and trafficking of migrants on 11 May 2015 (UNODC, 2020b). The law was called the Law 2015-36 and adopted the Palermo Declaration that prohibits the smuggling of migrants by land, air and sea (Perrin, 2020). Before Law 2015-36, the Agadez route supplied about 65,000 migrants per year with about $45 \%$ coming from Nigeria alone, and most of whom were from the southern part of the country (BenSaad, 2003).

In some cases, the decision to migrate is affected by fear of social rejection while in Europe. Though most migrants believed Covid-19 is neither prevalent in Nigeria nor in any of the transit countries, they are afraid that they are likely to face social rejection on account of Covid-19 suspicions. Regardless, they are confident of finding their way to be accepted provided they can prove their health status and maintain adherence to preventive requirements as they are doing in Niger. A 25-year old female migrant in Dirkou posited: "Someone told me blacks find it difficult to be accepted and because our countries do not have good hospitals they will think all migrants are Covid-19 positive, but I believe they will understand." This may not be unexpected as migrants have always been stigmatised in crisis situations (IOM, 2020a) and during Covid-19, xenophobia and racism are increasing in Europe (Vertovec, 2020) and could lead to political, social and medical exclusion or even violence and crime (KAICIID, 2020).

\section{Migrants Live in Difficult Socioeconomic Conditions during Covid-19}

Niger has had open access to health facilities for all foreigners even before Covid-19 and placed virtually no employment restrictions apart from strategic organisations like security establishments like the army and the police, the civil service and elective offices. Migrants therefore work as porters, in the fashion industry, marketing of wares, on the farms and in private offices. This they do to feed, clothe and pay for rent-most of the migrants have dependents, either their own children, old parents or siblings which they hope to send remittances back for their upkeep. However, only very few of the respondents are migrating with a dependent, which increases the burden of surviving the journey especially for an irregular migrant. This has been the trend for more than a decade and is not expected to change anytime soon (Charriere \& Fresia, 2008) leading to the conclusion that a quarter of all African migrants are children (UNICEF, 2019).

Around one in five of the respondents who were still in Nigeria, but who could not go back to their place of residence due to the interstate ban imposed in April 2020, engaged in petty trading along the Jibia-Dan Isa border: They commonly partake in selling second hand clothes, phone accessories and fruits. One respondent works as labourer in a construction site. These small-scale activities are common among both immigrants and emigrants in the country (Afolayan, 2009) and are mostly understood as temporary measures to earn income for food without deflating what was initially budgeted to finance the 'European dream.'

Migrants also face the dangers of human smuggling, where traffickers capitalise on migrants' desperation to feed their illegal businesses (Triandafyllidou \& McAuliffe, 2018; UNODC, 2018, 2020a) with the proportion of female migrants increasing rapidly and, in most cases, ending in prostitution networks (UNODC, 2011). One of the female respondents in Dirkou (Niger) posited that:

A travel agent asked me to pay $\$ 300,000$ [equivalents of 10 months' minimum wage in Nigeria] for him to take me to Gibraltar [before Covid-19]. I paid half and some men told me he could be a Yan Jigilan mutane [trafficker], so when I asked him to refund my money he said since I don't trust him I should go and trust those who distracted me.

In times of movement restrictions, migrants, especially women, are prone to trafficking and easy subjects of sexual abuse. Shelley (2014) reported that 12,500 women, about half of all prostitutes in Italy, are Nigerian women that are trafficked into the country. Human traffickers could be registered travel agents or disguised as one to gain the confidence of potential victims. When uncertainty is so high, trust becomes pertinent in taking decision to wobble through uncertain waters and 
reach Europe or distrust the 'agents' and stay foot. The travel agents replicate their experiences of finding a way through, especially within Africa where border officials pretend to allow legal travellers loaded on trucks to legal destinations and "pretend to ignore the final destination" (BenSaad, 2003). Smuggling of migrants generally increases by the day in both volume and sophistication (Anderson, 2016). The Nigerian groups are particularly noted to be highly structured: They try several methods of crossing over (UNODC, 2011) and hold the record of most success stories in reaching Europe (BenSaad, 2003). However, the fact that migrants are willingly engaging with the services of smugglers indicates that they may not be truly victims of traffickers. Sometimes they initiate the journey themselves, finance it and partner with the traffickers to facilitate their mission, as observed by Haas (2008).

All the migrants interviewed in Nigeria and the Republic of the Niger stated that they adhered to Covid-19 preventive measures provided by the countries. Indeed, the migrants I talked to in Niger expressed concerns that not all those who have shown signs of the disease are tested to ascertain their health status. However, they do not consider it a sign of discrimination against the migrants because the same limited testing also applies to citizens, primarily due to the shortage of laboratories that conduct the test in the country. Furthermore, "to reduce spread of the pandemic, nongovernmental organisations such as IOM stepped up to create awareness and encourage preventive measures to protect stranded migrants in the country" (IOM, 2020b). Consequently, this resulted in emotional and physical stress because of the fear of infection and the knowledge that they are far away from relatives and their government, as well as the sudden change in ways of life especially being confined to one's room for a long time.

\section{Migrants Have Mixed Expectations Regarding Post-Covid-19 Situations}

Few migrants have the feeling that the economic crisis brought by the pandemic may result in rejection of migrants at workplaces due to job scarcity in European countries. It is predicted that Covid-19 will drive migrants to further unemployment and underemployment (Guadagno, 2020) with young migrants more likely to hold informal jobs and likely to be plunged into food and nutritional insecurity (Food and Agriculture Organisation, 2020). The majority are very confident of getting a job and being integrated into European society once they arrive at the shores of Europe. Nevertheless, the hopes are neither built on reliable travel guidance nor any plan, but on hearsay and expectations, including scenes from European films. A 26-year old migrant in Agadez said: "We are seeing how they live their lives on TV, and if you compare it to our own, you can only hope to be there."

Backlog of visa and travel applications may complicate regular migration processes and could easily spur an increase in the cases of irregular migration giving travel agents enough preys to feed on. As one respondent put it: "Many of us are waiting to apply for visa but some of us are resorting to travel agents but their fees are exorbitant." Increase in human trafficking is therefore a likely occurrence, especially across the Western Sahara, because the European externalisation of border control stepped up control measures in the Sahara to an extent that even legitimate travels are now made difficult by instruments such as Law 2015-36. Such restrictions are pushing travel agents to devise means of circumventing the laws by increasing the sophistication of human smuggling (Perrin, 2020; UNODC, 2020b). However, one of the respondents had a contrasting view: "What my elder brother used to send back home has stopped and it is all because he lost his job due to this Corona, so I am thinking of whether I can really get job if I join him in Valencia." Hence, he sounds discouraged by the hard economic realities of receiving nations.

\section{Discussion}

It is established that Covid-19 halts both regular and irregular migration due to the lockdown of cities and consular services as well as cross border travel restrictions that limits mobility of irregular migrants (Chike, 2020; Migration Data Portal, 2020; Yayboke, 2020). However, this points to only a temporary hitch resulting in accrual of intending migrants waiting for an opening. While fear of the disease is not a factor that stops migrants, the movement restrictions associated with the pandemic does (John, 2020). As soon as borders open again, Nigerian, Moroccan, Libyan and Europeans authorities, especially Spain and Italy, will have a hectic job of policing borders, deserts and waters to save lives and ensure adherence to national, regional and international laws of migration such as the 2015 Nigerian Immigration Act, the Law 2015-36, the ECOWAS' Common Approach on Migration and the UNHCR Policy Framework and Implementation Strategy. This route, as confirmed by the UNODC, is the most frequented by irregular migrants originating "from the Gulf of Guinea, crosses Mali and Niger and leads North, through Algeria, where it bifurcates east towards Libya and west towards Morocco. Agadez in Niger, Gao and Kidal in Mali, and Tamanrasset in Algeria are transit nodes" (UNODC, 2010).

After a temporary reduction in mobility along the Sub-Saharan and Mediterranean routes, migration flows from less developed countries have already picked up in June and the increase is sustained over the three months that follows, recording a total of 13,150 illegal crossings (UNODC, 2010), an increase of $155 \%$ from last year (Bielby, 2020; Yayboke, 2020). These findings validate the Raveinstein's (1885) claims that migrants are more inclined to short journeys thereby moving to nearby economic hubs on routes to destinations. This is because migrants along the Nigeria/Niger/Libya corridor are found to be organising their journeys in stages. 
They first assemble in the Nigerian cities of Kano or Katsina, where they usually engage agents and sometimes make payments before stopping again in cities like Agadez or Dirkou (Niger) to work and earn money to facilitate the journey. Here they wait for the 'right moment' to move, as determined by the travel agents. When they reach Libya or Morocco, again they wait for another 'right moment' to sail across the Mediterranean. Nigerian migrants usually regroup in Nigerian cities such as Kano and Katsina and pay for their journeys in advance before reaching the doors of the Sahara via Nigerien cities such as Agadez and Niamey (UNODC, 2011).

This is because an increase in the rate of irregular migration from Nigeria and other West African countries to Europe after Covid-19 looks impending (Yayboke, 2020), and factors that accelerate the increase such as economic failures due to low oil prices (Onyekwena \& Ekeruche, 2020), insurgency and other forms of insecurity (World Bank, 2020b), desertification and climate change-induced agricultural failures abound in Nigeria making the country's recession in worst in four decades (World Bank, 2020c). In this sense, uncertainties around Covid-19 and border crossing add just a little bit to a long list of uncertainties that characterise the expected migration experience of the respondents. On the pull side, the real and perceived opportunities in Europe makes migrants consider their journey a solution to misery, and thereby worth taking risks even through dangerous paths.

Imminently, the future of migration in West Africa will be dominated by smugglers and traffickers alike who masquerade as travel agencies and operate through clandestine methods to lure migrants (UNODC, 2020a) often robbing migrants on the way and abandoning them in the desert (BenSaad, 2003). With rising migrants' desperation and determined border surveillance by national authorities, travel agents claim to provide the solution which eventually attract lots of migrants (Fleshman, 2009; Shelley, 2014) resulting in more Nigerians being stranded in North Africa after unsuccessful attempts to reach Europe (UNODC, 2011). National and multinational arrangements to curb irregular migration and human trafficking will therefore face hectic times to deal with voyages of doom (Sawadogo, 2012)

Most migrants are building their hope on hearsay and fantasising European lifestyles without certainty of reaching Europe, obtaining a job and living a decent life. However, it can be hypothesised that with closure of companies and other economic activities in Europe, jobs are likely to be scarce, making it difficult to accommodate the stock of migrants heading to the Mediterranean waters to reach Europe. In the long run, a high supply of the migrant labour force, and a shortage of work opportunities will result in increasing migrant unemployment and migrants' willingness to return home while some may could be forced by circumstances to accept demeaning undeclared works with low pay, increased hours of work and against the national labour labour especially in agriculture and the building industry (International Labour Organisation, 2010) while the authorities and company owners leverage on the exploitation of cheap labour that enables them derive huge profits and afford the citizens opportunity to purchase quality produces at comparatively low prices (Bell, 2003). Millions of migrant workers battling poverty and unemployment are already returning home across the world after losing their jobs due to Covid-19 (International Labour Organisation, 2020). In Spain, migrant unemployment increased after the onset of Covid-19 to 70,200 (24\% of total migrant population in the country) compared to 15,200 among nationals (European Union, 2020).

Uncertainty and Fear of social rejection and health induced stigmatisation could become certain especially when they reach Europe without proper documentation that will indicate their health status. This could be worse if European far right politicians use Covid-19 excuses to push for more restrictions against migrants which could affect social inclusion initiatives across the continent (Vertovec, 2020).

Most of the findings support Lee's (1966) assumptions that in both place of origin and place of destination there are many positive factors that keep people from moving and attract others to come in as well as negative factors that send people away and repel migrants. The essentiality of negative and positive factors in taking migration decision is however shaped by personal factors such as knowledge, awareness, intelligence, social connection and perception of the negative and positive factors that can be easily exaggerated or underplayed depending on the personal factors (Amaral, 2018). This explains the perceived greener pasture in Europe and repelling factors in Nigeria.

Hence, uncertainty regarding fears and expectations as perceived by individuals control decision of migrants moving from Nigeria through dangerous intervening obstacles to Europe.

\section{Conclusion}

This article examines the perceptions of Nigerian migrants en route to Europe via Niger who were affected by the Covid-19 movement restrictions. It documents their feelings, fears, living conditions and expectations with particular reference to the relationship between the pandemic and the intention or otherwise of migrants to engage in the voyage to Europe amidst the uncertainties and restriction wrought by the pandemic. This article reviewed stakeholder perceptions and related them to current literature in the field to validate claims, examine migration trends and predict future of migration from Nigeria to Europe.

The article concludes that migration-especially irregular movements-will probably increase in post Covid-19 times, as the respondents regard the pandemic only as a temporary setback as the decision to migrate to Europe remains unchanged. On the journey however, 
migrants lived in difficult socioeconomic circumstances including personal and food insecurity, lack of shelter, and health challenges. As found by other researchers (Anderson, 2016; BenSaad, 2003), this article confirmed that migrants are often stripped of their properties, robbed and called degrading names while on transit especially where they are warehoused, tortured and maltreated with impunity in transit countries. Migrants also face challenges from the activities of traffickers that are cashing on migrants' desperation. Impliedly, the current consideration of migration across the Mediterranean as both a security and humanitarian challenge will continue beyond the pandemic in a passion described by Norman Myers and Jacques Chirac (as cited in Haas, 2008, p. 2) as a "flood" and the likely response of curtailing it will increase the propensity of trafficking (Haas, 2008) because the business blossoms whenever countries put more pressure to curtail illegal migration (Anderson, 2016). Thus, expectations of migrants when they reach Europe mirrors a flipped coin that is still in the air, either a greener pasture or a life of regret.

\section{Acknowledgments}

I wish to acknowledge the Swiss Sub-Saharan Africa Migration Network (S-SAM) for sponsoring the publication of this article. I also appreciate the professional guidance received from Prof. Didier Ruedin of University of Neuchatel, Switzerland, and Malam Muhammad Kaku of the Public Administration Department, Federal Polytechnic Damaturu, Nigeria, for conducting the interviews.

\section{Conflict of Interests}

The author declares no conflict of interests.

\section{References}

Afolayan, A. (2009). Migration in Nigeria: A country profile 2009. Geneva: International Organization for Migration. Retrieved from https://reliefweb.int/ sites/reliefweb.int/files/resources/96194F75629D33 5BC1257769003746BD-Full_report.pdf

Ahsan, R., Iqbal, K., Khan, M., \& Mobarak, A. M. (2020). Using migration patterns to predict Covid-19 risk exposure in developing countries. Yale: Yale Y-Rise.

Amaral, E. F. (2018). Migration theories [PowerPoint presentation]. Retrieved from http://www.ernesto amaral.com/docs/soci647-18spring/Lecture02.pdf

Anderson, R. (2016). Europe's failed 'fight' against irregular migration: Ethnographic notes on a counterproductive industry. Journal of Ethnic and Migration Studies, 42(7), 1055-1075.

Artis, P. D., Carlei, S., \& Bouteller, F. (2020). Nigeria: Covid-19-Immigration update. Le Blog De Taj. Retrieved from https://taj-strategie.fr/nigeria-Covid19-immigration-update
Bearzotti, E., Geranio, A., Keresztes, V. K., \& Müllerová, M. (2015). Containing Boko Haram's transnational reach: Toward a developmental approach to border management. Vienna: Regional Academy on the United Nations. Retrieved from http://www. ra-un.org/uploads/4/7/5/4/47544571/containing_ boko_haram.pdf

Bell, N. (2003, February 11). The exploitation of migrants in Europe. Civique Forum. Retrieved from https://forumcivique.org/fr/artikel/the-exploitationof-migrants-in-europe

BenSaad, A. (2003). Agadez, migratory crossroads Sahelo-Maghrebian. European Journal of International Migration, 19(1), 7-28.

Bielby, K. (2020, August 22). Migrants die at sea as illegal border crossings start to pick up around Europe. Homeland Security. Retrieved from https:// www.hstoday.us/subject-matter-areas/bordersecurity/illegal-border-crossings-start-to-pick-uparound-europe-as-migrants-die-at-sea

Brachet, J. (2018). Manufacturing smugglers: From irregular to clandestine mobility in the Sahara. Annals of the American Academy of Political and Social Sciences, 676(1). https://doi.org/10.1177/ 0002716217744529

Charriere, F., \& Fresia, M. (2008). West Africa as a migration and protection area. Geneva: UNHCR. Retrieved from https://www.refworld.org/pdfid/ 4a277db82.pdf

Chike, O. (2020, July 10). Covid-19: British high commission to resume Visa application in Nigeria. Nairametrics. Retrieved from https://nairametrics.com/ 2020/07/10/Covid-19-british-high-commission-toresume-visa-application-in-nigeria

Economic Community of West African States. (2008). ECOWAS common approach on migration: 33rd ordinary session of the head of state and government. Ouagadougou: CEDEAO.

European Union. (2020). Spain: Migrant unemployment rate rises after covid-19. European Web Site on Integration. Retrieved from https://ec.europa.eu/ migrant-integration/news/spain-migrantunemployment-rate-rises-after-covid-19

Fleshman, M. (2009). Africa fights the peoples' trade: The scourge of human trafficking ensnares hundreds of thousands. United Nations Africa Renewal. Retrieved from https://www.un.org/africarenewal/ magazine/october-2009/africa-fights-\%E2\%80\%98 people-trade\%E2\%80\%99

Food and Agriculture Organisation. (2020). Migrant workers and the covid-19 pandemic. Rome: Food and Agriculture Organisation of the United Nations. Retrieved from http://www.fao.org/3/ca8559en/ CA8559EN.pdf

Frowd, P. (2014). The field of border control in Mauritania. Security Dialogue, 45(3), 226-241.

Gagnon, J. (2020). Covid-19: Consequences for international migration and development. OECD- 
Development Matters. Retrieved from https://oecddevelopment-matters.org/2020/04/02/Covid-19consequences-for-international-migration-anddevelopment

Guadagno, L. (2020). Migrants and the Covid-19 pandemic: An initial analysis. Grand-Saconnex: International Office for Migration. Retrieved from https:// publications.iom.int/system/files/pdf/mrs-60.pdf

Haas, H. D. (2008). The myth of invasion: The inconvenient realities of African migration to Europe. Third World Quarterly, 29(7), 1305-1322.

Hossin, M. Z. (2020). International migration and health: It is time to go beyond conventional theoretical frameworks. BMJ Global Health, 5(2). http://dx.doi. org/10.1136/bmjgh-2019-001938

International Labour Organisation. (2010). Labour inspection in Europe: Undeclared work, migration, trafficking. International Labour Organisation. Retrieved from https://www.ilo.org/labadmin/info/ pubs/WCMS_120319/lang--en/index.htm

International Labour Organisation. (2020). ILO warns of Covid-19 migrant 'crisis within a crisis. International Labour Organisation. Retrieved from https:// www.ilo.org/global/about-the-ilo/newsroom/news/ WCMS_748992/lang--en/index.htm

International Organisation for Migration. (2020a). Understanding the migration \& mobility implications of Covid-19. Grand-Saconnex: International Office for Migration. Retrieved from https://www. iom.int/sites/default/files/documents/Covid-19_ analytical_snapshot_6_-_stigmatization_and_ discrimination.pdf

International Organisation for Migration. (2020b). IOM steps up response for migrants stranded in Niger amidst COVID-19 lockdown. United Nations Africa Renewal. Retrieved from https://www.un. org/africarenewal/news/coronavirus/iom-stepsresponse-migrants-stranded-niger-amidst-Covid-19lockdown

John, E. (2020). Covid-19 Implications for public transport and shared taxis in Nigeria. TUMITransformative Urban Mobility Initiative. Retrieved from https://www.transformative-mobility.org/ news/covid-19-implications-for-public-transportand-shared-taxi-in-nigeria

KAICIID. (2020). Refugees and migrants in Europe: Discrimination and xenophobia during Covid-19. King Abdullah bin Abdulaziz International Center for Interreligious and Intercultural Dialogue. Retrieved from https://www.kaiciid.org/dialogue-knowledgehub/webinars/refugees-and-migrants-europediscrimination-and-xenophobia-during

Lee, E. S. (1966). A theory of migration. Demography, 3(1), 47-57.

Migration Data Portal. (2020). Migration data relevant for the Covid-19 pandemic. Migration Data Portal. Retrieved from https://migrationdataportal.org/ themes/migration-data-relevant-Covid-19- pandemic

Natter, K., Czaika, M., \& Haas, H. d. (2020). Political party ideology and immigration policy reform: An empirical enquiry. Political Research Exchange, 2(1). https:// doi.org/10.1080/2474736X.2020.1735255

Onyekwena, C., \& Ekeruche, M. A. (2020). Understanding the impact of the Covid-19 outbreak on the Nigerian economy. Brookings: Africa in Focus. Retrieved from https://www.brookings.edu/blog/africa-in-focus/ 2020/04/08/understanding-the-impact-of-theCovid-19-outbreak-on-the-nigerian-economy

Perrin, D. (2020). Smuggling of migrants: The misused spirit of the Palermo Protocol, in the light of the Nigerien experience. Border Criminologies. Retrieved from https://www.law.ox.ac.uk/researchsubject-groups/centre-criminology/centrebordercriminologies/blog/2020/05/smuggling\#: :text= Law\%202015\%2D36\%20was\%20adopted,Organized \%20Crime\%2C\%20adopted\%20in\%202000

Ramji-Nogales, J., \& Lang, I. G. (2020). Freedom of movement, migration, and borders. Journal of Human Rights, 19(5), 592-602. https://doi.org/10.1080/ 14754835.2020.1830045

Raveinstein, E.G., (1885). The laws of migration. Journal of the Statistical Society of London, 48(2), 167-235. Retrieved from https://www.jstor.org/stable/ 2979181?seq=1

Sawadogo, W. R. (2012). The challenges of transnational human trafficking in West Africa. African Studies Quarterly, 13(1/2), 95-115.

Shelley, L. (2014). Human smuggling and trafficking into Europe: A comparative perspective. Washington, DC: Migration Policy Institute. Retrieved from https://www.migrationpolicy.org/sites/default/ files/publications/BadActors-ShelleyFINALWEB.pdf

Triandafyllidou, A., \& McAuliffe, M. (Eds.). (2018). Migrant smuggling data and research: A global review of the emerging evidence base (Vol. 2). Geneva: International Organization for Migration.

UNICEF. (2019). Data snapshot of migrant and displaced children in Africa. UNICEF. Retrieved from https://data.unicef.org/resources/data-snapshotof-migrant-and-displaced-children-in-africa

United Nations Office on Drugs and Crime. (2010). Smuggling migrants: A global review and annotated bibliography of recent publications. Vienna: United Nation Office on Drugs and Crime. Retrieved from http://lastradainternational.org/lsidocs/Smuggling_ of_Migrants_A_Global_Review.pdf

United Nations Office on Drugs and Crime. (2011). Smuggling of migrants: A global review and annotated bibliography of recent publications. Vienna: United Nation Office on Drugs and Crime. Retrieved from https://www.unodc.org/documents/humantrafficking/Migrant-Smuggling/Smuggling_of_ Migrants_A_Global_Review.pdf

United Nations Office on Drugs and Crime. (2018, September 24). Prosecutors from Africa and Europe 
agree closer cooperation against human trafficking and migrant smuggling. United Nations Office on Drugs and Crime. Retrieved from https://www. unodc.org/unodc/en/frontpage/2018/September/ prosecutors-from-africa-and-europe-agree-tocloser-cooperation-against-human-trafficking-andmigrant-smuggling.html

United Nations Office on Drugs and Crime. (2020a, January 1). Human trafficking and smuggling of migrants. United Nations Office on Drugs and Crime. Retrieved from https://www.unodc.org/westandcentralafrica/ en/newrosenwebsite/TIPSOM/Human-traffickingand-smuggling-of-migrants.html

United Nations Office on Drugs and Crime. (2020b, January 1). Niger becomes the first Sahel country to legislate against migrant smuggling. United Nations Office on Drugs and Crime. Retrieved from https://www.unodc.org/westandcentralafrica/ en/niger-som-law.html

Vertovec, S. (2020). Covid-19 and enduring stigma: The Corona pandemic increases xenophobia and exclusion worldwide. Max-Planck-Gesellschaft. Max Planck Institute for the Study of Ethnic and Religious Diversity. Retrieved from https://www.mpg. de/14741776/Covid-19-and-enduring-stigma

World Bank. (2020a). Covid-19 through migration lens
(Migration and Development Brief). Washington, DC: World Bank Publications.

World Bank. (2020b). Nigeria development update: Rebuilding after Covid-19. The World Bank Group. Retrieved from https://www.worldbank.org/en/ country/nigeria/publication/nigeria-developmentupdate-rebuilding-after-Covid19

World Bank. (2020c). Nigeria in times of Covid-19: Laying foundations for a strong recovery. Nigeria development update. Washington, DC: World Bank Publications. Retrieved from http://documents1. worldbank.org/curated/en/695491593024516552/ pdf/Nigeria-in-Times-of-Covid-19-LayingFoundations-for-a-Strong-Recovery.pdf

World Bank. (2020d). The global economic outlook during the Covid-19 Pandemic: A changed world. The World Bank Group. Retrieved https:// www.worldbank.org/en/news/feature/2020/06/08/ the-global-economic-outlook-during-the-covid-19pandemic-a-changed-world

Xhardez, C. (2020). Can Covid-19 positively change perceptions on migration. Washington, DC: Open Democracy.

Yayboke, E. (2020). Five ways Covid-19 is changing global Migration. Washington DC: Center for Strategic \& International Studies.

\section{About the Author}

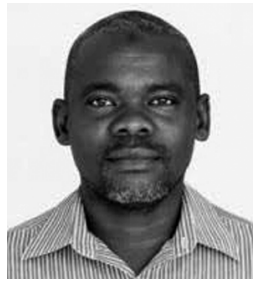

Lawan Cheri holds PhD in Public Administration from the University of Maiduguri and has a strong interest in conflict and migration studies. He is a Principal Lecturer and Head at the Department of Public Administration, Federal Polytechnic Damaturu, and a Visiting Senior Lecturer at Yobe State University, Damaturu. He currently teaches courses on conflict resolution and management, policy formulation and analysis and African Politics at Yobe State University, Damaturu. He writes on migration, displacement, policy changes and dialogue. 